\title{
Sludge of Oil Refining Units and Their Processing
}

\author{
Volodymyr Chelyadyn', Mykola Bogoslavets², Liubomyr Chelyadyn ${ }^{3 *}$, \\ Oksana Poznyak ${ }^{4}$, Petro Novosad ${ }^{4}$
}

1 G.V. Kurdyumov Institute for Metal Physics, NAS of Ukraine, 36 Academician Vernadskyy Boulevard, 03680, Kyiv, Ukraine

2 Naftokhimik Prykarpattya, PJSC, 5 Maydanska Street, Nadvirna, 78400, Ivano-Frankivsk Region, Ukraine

${ }^{3}$ Ivano-Frankivsk National Technical University of Oil and Gas, 15 Karpatska Street, 76019, Ivano-Frankivsk, Ukraine

${ }^{4}$ Lviv Polytechnic National University, 12 Stepan Bandera Street, 79013, Lviv, Ukraine

* Corresponding author's e-mail: chelyadyn@ukr.net

\begin{abstract}
The article presents the quantitative characteristics of multi-tonnage technogenic wastes in Ukraine and the IvanoFrankivsk region, which cause environmental pollution. The water silts containing petroleum products are particularly dangerous wastes. It is proposed to recycle them using the method of preparation of the raw mixture in composition with the following technogenic wastes: oil sludge, ash, zeolite material, calcium-containing compounds, and organic mineral binders. They are granulated and subjected to the thermal treatment at low temperatures. The granular materials made using the oil-containing silt of the model object reduce the negative impact onto the environment of the region and increase its level of environmental safety.
\end{abstract}

Keywords: environment, petroleum products, toxic components, water purification, utilization of oil sludge, zeolite clinoptilolite, wastewater, fly ash

\section{INTRODUCTION}

The society development leads to an increase in the consumption of natural resources, caused by the occurrence of new technologies and materials. It also results in the appearance and rapid increase of technogenic wastes, wastewaters, and emissions that are dangerous for the environment; therefore, the problem of waste management is urgent not only for Ukraine, but also for the whole world. The accumulation of anthropogenic wastes on unauthorized and unmanaged landfills and their contact with water resources lead to the penetration of harmful chemical and biological elements into the environment, significantly reducing the level of environmental safety of the region.

The main causes of technogenic pollution include the insufficiently treated wastewaters, solid technogenic wastes, and emissions of harmful substances into the atmosphere, which are generated at industrial enterprises as a result of their production and livelihood of workers. They have a significant impact onto the health of the local population, biodiversity, and environmental safety of the region.

Significant amount of wastes was generated in Ukraine during 2017 (Prokopenko 2018), which is equal to about 366,054 thousand tons, including $1,948.8$ thousand tons in the IvanoFrankivsk region (6.9 thousand tons with the compounds of the elements of the $1^{\text {st }}-3^{\text {rd }}$ classes of danger and combustion wastes in the amount of $1,036.3$ thousand tons were directed to specially designated places or objects). For example, the 204 ha multi-tonnage dump of Burshtyn TPP with the wastes in the amount of 969.8 thousand tons pollutes the atmosphere and water resources. The amount of wastes in the water supply system that was generated during 2017 in the IvanoFrankivsk region [Blinnikova 2018] is equal to about 150 thousand tons: 36 thousand tons were 
generated by the wastewater treatment plants of the Ivano-Frankivsk town and 8.5 thousand tons were produced by Nadvirna town, including 2.7 thousand tons of oil-containing sludge, stored in the silt fields or garners of the town oil refinery and polluting the environment.

The important problems of the Ukrainian oil refining industry include the disposal of the improper petroleum feedstock and silt that form during the treatment of wastewaters with petroleum products (Dolina 2005, Vdovenko et al. 2015). They contain a large amount of petroleum products in a suspended form.

The oil-containing sludge is a complex physical and chemical mixture that consists of petroleum products, mechanical impurities (clay, metal oxides, and sand), and water (Tsymbalyuk 2011). The composition of this sludge is a stable multicomponent formation, consisting of various petroleum products, as well as water and mineral inclusions in the form of sand, silt, and metal oxides. They are generated by physical processes, namely adsorption and absorption, combined with the property of petroleum products to create emulsions with different decomposition resistances. These waste types accumulate in certain places called sludge ponds, where they come into contact with the atmosphere, water, and soil and thus adversely affect the environment. This effect can be mitigated by the conversion and disposal of oil-containing silt, wastes of petroleum products, and wastewater sludges that accumulated at and outside oil refinery.

Transformation of the oil-containing sludge is an important environmental and economic task for the petroleum industry (Borodin 2016, Brauweiler et al. 2017). This treatment is designed to conduct waste-free cleaning and disposal, as well as use standard equipment, cost-effective and environment-friendly technologies.

There are various methods for the disposal of the oil-containing sludge. For example, one of them consists in burning of the oil-containing sludge by adding it to various building mixtures as a filler or plasticizer in some energy-intensive industries (Akhmetov et al. 2011, Jamali et al. 2015).

Currently, there are several methods, used for silt disposal: decomposition into petroleum product, water, and solid mechanical residues with the help of modern centrifuges, separators, and decanters, or burning of partially dehydrated silt in special furnaces (Jamali et al., 2015, Johnson et al. 2019). The principles of their action are described below.

There is a method for processing dry or moistened silt (Vozniuk et al. 2006) by means of the extraction of petroleum products from the surfaces of solid-phase particles, using the solvent, which can mix with dry or moistened silt at the temperature up to $70-80{ }^{\circ} \mathrm{C}$. The petroleum products are removed and cyclically used to wash further portions of the sludge and the petroleum products, remaining after the solvent has been separated from the squeezed solution; they are removed from the process as the solid phase purified residue.

The method for thermal disposal of oil sludge (Rudiuk et al. 2006) includes the pyrolysis without air access in order to obtain a solid carbon residue and multi-component steam-and-gas mixture, as well as multi-stage circulation cooling of the steam-and-gas mixture, its breakdown into components in the form of condensate of various fractions, return of the condensate of greater fractions, and condensation of the original steamand-gas mixture in the original condenser in order to obtain the pyrolysis gas and liquid fuel.

The method for processing stable oil emulsions and old oil sludge (Nazarov et al. 2013) involves steam heating, reduction of the oil sludge water content to the level that does not exceed $50 \mathrm{wt} . \%$ and removal of the oil products to produce mazut.

The unit for oil silt thermal disposal (Mazlova et al. 2001) contains the pyrolysis reactor with screws, external heating system, loading and unloading pipe for drainage and steam-and-gas mixture, cooler steam-and-gas mixture, and output capacitor with water cooling.

The studies cited in Vambol et al. (2015) present the technologies and equipment for the disposal of carbon wastes, using the method for their gasification. The process flow diagram that allows obtaining gas with high methane content, sufficient for its use as a motor fuel and fuel gas to support the process of step-by-step high-temperature treatment of wastes in the thermo-chemical gas generator and additional gasification in the plasma gas generator, associated with the emission of fuel gas, which may be the secondary energy resource, reducing energy costs, was proposed on the basis of the carried out studies and obtained results.

The study of fly ash processing is provided in (Chelyadyn 2018), where "Raw mixture" and 
"Methods for obtaining porous thermal insulation material" that are patented (Chelyadyn et al. 2018, Chelyadyn 2010) were proposed based on the TPP of the respective fraction. The theoretical and experimental studies used in the work, concern determination of the optimum composition of the raw mixture and the properties of the obtained thermal insulation material.

High-strength self-compacting concretes with the content of fly ash in the binder composition up to $55 \mathrm{wt} . \%$ and aerated concretes, where fly ash was used as a filler for obtaining structural insulated composites, were produced in works (Stechyshyn et al. 2015, Novosad et al. 2020) using fly ash removal of Burshtyn TPP.

The article (Chelyadyn et al. 2016) shows that the main direction for reducing the negative impact of technogenic wastes onto the environment, is their conversion into construction materials and products. The technogenic wastes are used to make a mixture with the following ratio, wt.\%: fly ash $-80-85$, soda $-5-8$, sawdust $-7-9$, carbonate wastes $-6-8$, liquid glass $-5-9$. The specified elements are subjected to granulation, thermal treatment at the temperatures within the range of $80-110^{\circ} \mathrm{C}$, thus resulting in the creation of foamsilicate materials.

The patent (Chelyadyn et al. 2018) describes the composition of the raw mixture, which includes inorganic and organic materials in the following proportions, wt.\%: TPP fly ash -65.0 75.0; wastes of carbonate compounds - 5.0-10.0; polymer wastes - other.

On the basis of the results of the studies (Chelyadyn, Bogoslavets et al. 2016), it was found that the wastewater sludge with petroleum products of oil refinery can be used as an energy-efficient additive when producing carbon-mineral materials, studied as a filtering material, sorbent of emissions of contaminated gas, and filler of construction products during water treatment processes.

It was established (Nadesan et al. 2017; Novosad et al. 2009) that the TPP ash slag as a microfiller causes a decrease in the intergranular cavity and, when combined with other chemical impurities, allows obtaining a material with an increased strength and porosity.

The TPP fly ash and slag wastes contain a significant amount of silicon oxide (it occupies the $2^{\text {nd }}$ place in the cement mixture) and calciumcontaining compounds, which make the main constituent part of the cement and affect its quality (Bogoslavets 2018). The TPP fly ash should be studied as an effective additive in the process of cement production.

However, the scale of disposal of the TPP fly ash and oil-containing sludge that are regenerated is not more than $15 \%$ of the amount formed.

It is known that the cement production process is energy intensive and the sludge of the water treatment plant contains the hydrocarbons that produce heat during combustion - it is desirable to have such a component in the furnace charge of the energy intensive productions. Therefore, the raw mixture of the ash slag and refinery sludge with some other additives can be effective in cement production.

The objective of the study was to determine the optimal component composition of the raw mixture of the oil-containing sludge with technogenic wastes and natural additives, as well as to develop a new technology for its transformation into a resource-and-energy granular material for cement production.

\section{MATERIAL AND METHODS}

The material was the sludge with petroleum products and wastewaters, which form at the treatment plants of Naftokhimik Prykarpattya, PJSC (Nadvirna town), as well as the fly ash and sludge wastes from Burshtyn TPP.

In order to dispose of the above mentioned wastes, it is important to know their average composition. The sludge content of Nadvirna oil refinery (NNPZ) is as follows, wt.\%: petroleum products - 20-71; water - 21-66; mechanical impurities - 5-10; other - 2-6 (Vdovenko et al. 2015; Bogoslavets 2018). The main parameters of the samples of the oil and wastewater sludges from other refineries in Kremenchuk (KNPZ) and Drohobych (DNPZ) are provided in Table 1.

The OR oil-containing sludge, TPP fly ash, and limestone and zeolite mining wastes were used as the main components for the preparation of the granular material raw mixture. Some slag, fly ash, zeolite clinoptilolite, and calcium compounds were utilized for the disposal of oil sludge with obtainment of granules and their subsequent use.

The chemical composition of raw materials is presented in Tables 2 and 3.

The quantitative analysis of the materials was carried out, using the ARL-9800 wave X-ray 
Table 1. Average composition of individual sludge samples with petroleum products from oil refineries

\begin{tabular}{|c|c|c|c|c|c|c|c|c|c|}
\hline \multirow{2}{*}{ Component } & \multicolumn{9}{|c|}{ Object name } \\
\hline & \multicolumn{3}{|c|}{ NNPZ } & \multicolumn{3}{|c|}{ KNNZ } & \multicolumn{3}{|c|}{ DNPZ } \\
\hline Sample name & SL1 & SL2 & SL3 & SL4 & SL5 & SL6 & SL7 & SL8 & SL9 \\
\hline Petroleum products, $\%$ & 20.2 & 57.3 & 70.8 & 56.2 & 60.9 & 62.5 & 35.1 & 49.5 & 63.4 \\
\hline Water, \% & 65.5 & 28.4 & 21.7 & 30.2 & 24.1 & 20.3 & 37.9 & 35.7 & 21.8 \\
\hline Mechanical impurities, \% & 10.6 & 8.1 & 5.5 & 8.4 & 10.1 & 9.4 & 19.8 & 11.5 & 8.3 \\
\hline Traces, $\%$ & 3.7 & 6.2 & 2.0 & 5.2 & 4.9 & 7.8 & 7.2 & 3.3 & 6.5 \\
\hline
\end{tabular}

Table 2. Average chemical composition of the TTP wastes

\begin{tabular}{|l|c|c|c|c|c|c|c|c|}
\hline Waste Component, \% & $\mathrm{SiO}_{2}$ & $\mathrm{Al}_{2} \mathrm{O}_{3}$ & $\mathrm{Fe}_{2} \mathrm{O}_{3}$ & $\mathrm{Na}_{2} \mathrm{O}$ & $\mathrm{CaO}$ & $\mathrm{MgO}$ & $\mathrm{K}_{2} \mathrm{O}$ & $\begin{array}{c}\mathrm{H}_{2} \mathrm{O} \text { and } \\
\text { others }\end{array}$ \\
\hline Slag & 51.4 & 20.3 & 10.8 & 0.3 & 2.5 & 1.2 & 2.2 & 5.6 \\
\hline Fly ash & 48.46 & 24.90 & 15.93 & 2.73 & 1.54 & 1.96 & 3.45 & 1.03 \\
\hline
\end{tabular}

fluorescence spectrometer, factory number $262 \mathrm{XP}$ (Thermo Electron Co, Switzerland).

The composition of the raw mixture for cement production (except fly ash and sludge with petroleum products) should contain some mineral supplements such as zeolite clinoptilolite and calcium compounds for sorption of moisture and some metals that are offered to be converted into the cement mixture energy granular additive. Such additives will reduce the silt moisture and increase the calcium content, which is a major cement component. It is known that the substance absorption intensity increases along with the effective specific surface of the layer and contact area of the phases when the grain diameter of the sorbent (zeolite clinoptilolite) decreases. The preprepared zeolite rock samples in the dropout fraction of $0 \div 1 \mathrm{~mm}$ were used for the experiments.

Taking into account the fact that the granulation process is best conducted in a screw device and it requires a viscous feedstock, carboxymethylcellulose was studied as a binding substance because it has adhesive properties. The general formula of $\mathrm{CMC}$ is $\left[\mathrm{C}_{6} \mathrm{H}_{7} \mathrm{O}_{2}(\mathrm{OH})_{3-}\right.$ $\left.{ }_{\mathrm{x}}\left(\mathrm{OCH}_{2} \mathrm{COOH}\right)_{\mathrm{x}}\right]_{\mathrm{n}}$, where $\mathrm{x}=0.08-1.5$.
The proposed method for the disposal of the technogenic wastes includes mixing of the materials, their granulation, and thermal treatment (Fig. 1).

The technology for the conversion of the silt with petroleum products is proposed to be as follows. The first stage of the technology consists in mixing of fly ash (A), oil sludge (B), carbonate compounds (C), zeolite flour (D), and binding component $(\mathrm{F})$.

A laboratory mill was used to mix fly ash, zeolite flour, calcium compounds, and petroleum wastes in certain proportions. The next technological operation of the proposed method is the formation of a mixture of the products, using a screw granulator, which is directed for thermal treatment during $1.5-2$ hour at $30-55^{\circ} \mathrm{C}$. The process of the granules treatment was carried out in a laboratory furnace.

The main indicators of the physico-mechanical tests of the obtained granular porous materials were conducted according to the methods given in (DSTU B V.2.7-264:2011). The average density and water absorption of the obtained porous materials, based on wastes, was determined according to (DSTU B V.2.7-170:2008)

Table 3. Average chemical composition of technogenic production wastes and other additives

\begin{tabular}{|c|c|c|c|c|c|c|c|c|}
\hline Component, \% & $\mathrm{SiO}_{2}$ & $\mathrm{Al}_{2} \mathrm{O}_{3}$ & $\mathrm{Fe}_{2} \mathrm{O}_{3}$ & $\mathrm{CaO}$ & $\mathrm{K}_{2} \mathrm{O}$ & $\mathrm{P}_{2} \mathrm{O}_{5}$ & $\mathrm{C}_{x} \mathrm{H}_{y}$ & $\begin{array}{c}\mathrm{H}_{2} \mathrm{O} \text { and } \\
\text { others }\end{array}$ \\
\hline $\begin{array}{l}\text { Limestone debris siftinged } \\
\text { fractions } 0 \div 20 \mathrm{~mm}\end{array}$ & 1.5 & 0.5 & 0.2 & 69.6 & 0.04 & - & - & 34.9 \\
\hline Sludge of water purification & 6.6 & 1.5 & 2.2 & 1.2 & 0.9 & - & 57.5 & 30.1 \\
\hline $\begin{array}{l}\text { Zeolite clinoptilolite siftinged } \\
\text { fractions } 0 \div 1 \mathrm{~mm}\end{array}$ & 71.5 & 13.1 & 0.9 & 2.1 & 5.03 & 0.03 & - & 7.34 \\
\hline $\begin{array}{l}\text { Carboxymethyl cellulose } \\
(\mathrm{CMC})^{*}\end{array}$ & - & - & - & - & - & - & 91.0 & 9.0 \\
\hline
\end{tabular}

* Contains traces of heavy metals (Fe, $\mathrm{Pb}, \mathrm{Cu}, \mathrm{Zn}$ and other elements). 


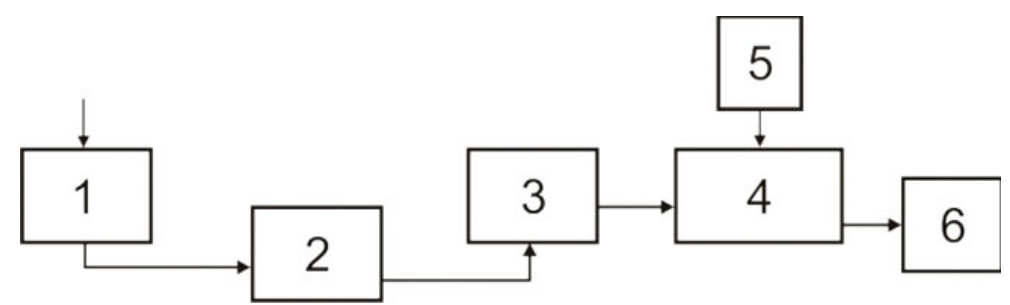

Fig. 1. Schematic diagram of processing of the oil-containing sludge and other technogenic wastes: 1 - sludge collector; 2 - sludge pump, 3 - material mixer, 4 - screw granulator, 5 - bins for bulk materials, 6 - thermoelectric apparatus.

and the strength was calculated according to (DSTU B V.2.7-214:2009).

The granules were subjected to compression by a cylinder plunger in order to determine the compressive strength with the help of the load, corresponding to the plunger immersion by $20 \mathrm{~mm}$ into the layer of the tested granule sample. The strength tests were performed, using a hydraulic press with the maximum force of $50 \mathrm{kN}$.

\section{RESULTS AND DISCUSSION}

The results, obtained with the help of the approbation laboratory tests of the processing of the oil-containing sludge from different industry sectors, are shown in Table 4.

In order to determine the effect of the CMC flow rate and duration of drying of the granules on their characteristics (bulk density of the granules and their strength), experimental studies were carried out in accordance with the plan of the two-factor and three-level experiment (Dvorkin et al. 2011), the variables of which are the CMC flow rate $\left(\mathrm{X}_{1}=2 ; 4 ; 6 \mathrm{wt} . \%\right)$ and duration of drying of the granules at the temperature of $40{ }^{\circ} \mathrm{C}\left(\mathrm{X}_{2}=1.0 ; 1.5 ; 2.0\right.$ hours $)$.
The essence of the experiments planning, using the mathematical method, consists in establishment of the mathematical relationship between the specified properties, composition, and technological parameters of obtainment of the materials.

The method of orthogonal central compositional planning provides a mathematical description of the process in the form of the following regression equation:

$\mathrm{Y}=\mathrm{B}_{0}+\mathrm{B}_{1} \mathrm{x}_{1}+\mathrm{B}_{2} \mathrm{x}_{2}+\mathrm{B}_{12} \mathrm{x}_{1} \mathrm{x}_{2}+\mathrm{B}_{11} \mathrm{x}_{1}^{2}+\mathrm{B}_{22} \mathrm{x}_{2}^{2}$,

where: $Y$-bulk density of the granules and their strength;

$\mathrm{X}_{1}$ - consumption rate of the $\mathrm{CMC}$;

$X_{2}$ - duration of drying of the granules at the temperature of $40{ }^{\circ} \mathrm{C} ; \mathrm{B}_{0}, \mathrm{~B}_{1}, \mathrm{~B}_{2}, \mathrm{~B}_{12}$, $\mathrm{B}_{11}, \mathrm{~B}_{22}$ - regression coefficients.

The main characteristics of the experiment plan, planning matrix, compositions of the raw mixtures, and results of the experiment are provided in Tables 5 and 6 . The following control parameters were selected when planning the experiment: $\mathrm{Y}_{1}$ and $\mathrm{Y}_{2}$ - bulk density of the granules and their strength respectively.

The regression coefficients were calculated, using the computer technology according to the algorithm of the program, especially developed in the Microsoft EXCEL spreadsheet, which

Table 4. Component ratios, process parameters, and material indicators

\begin{tabular}{|c|c|c|c|c|c|c|c|c|c|c|}
\hline $\begin{array}{c}\text { Number } \\
\text { of } \\
\text { sample }\end{array}$ & \multicolumn{4}{|c|}{ The composition of the mixture, g } & Temperature, & Time, hour & $\begin{array}{c}\text { Strength, } \\
\text { MPa }\end{array}$ & $\begin{array}{c}\text { Bulk } \\
\text { density, } \\
\mathrm{kg} / \mathrm{m}^{3}\end{array}$ & Porosity, \% \\
\hline 1 & 52.8 & 16.4 & 20.8 & 19.0 & 19.0 & 30 & 1.0 & 1.38 & 597 & 38 \\
\hline 3 & 51.6 & 13.9 & 19.9 & 14.7 & 14.7 & 35 & 1.0 & 2.76 & 585 & 33 \\
\hline 5 & 53.8 & 15.0 & 22.4 & 13.0 & 13.0 & 40 & 1.0 & 1.22 & 612 & 31 \\
\hline 6 & 45.3 & 18.9 & 24.5 & 11.4 & 11,4 & 40 & 1.5 & 2.22 & 574 & 34 \\
\hline 7 & 48.0 & 15.8 & 20.8 & 15.4 & 15.4 & 40 & 1.5 & 2.89 & 568 & 35 \\
\hline 8 & 41.8 & 14.2 & 19.9 & 15.1 & 15.1 & 45 & 1.5 & 2.22 & 521 & 36 \\
\hline 9 & 58.5 & 15.8 & 24.5 & 16.4 & 16.4 & 50 & 2.0 & 2.02 & 534 & 37 \\
\hline 10 & 60.4 & 15.8 & 24.5 & 17.4 & 17.4 & 55 & 2.0 & 2.31 & 608 & 30 \\
\hline
\end{tabular}


Table 5. Experiment plan that is typical of the CMC influence onto the flow rate and duration of drying of the granules onto their bulk density and strength

\begin{tabular}{|c|c|c|}
\hline \multirow{2}{*}{ Characteristics } & \multicolumn{2}{|c|}{ Factors } \\
\cline { 2 - 3 } & $\begin{array}{c}\text { Flow rate of } \\
\text { CMC } \\
\left(\mathrm{X}_{1}\right)\end{array}$ & $\begin{array}{c}\text { Drying duration of } \\
\text { the granules at a } \\
\text { temperature of } 40^{\circ} \mathrm{C}, \\
\text { hour }\left(\mathrm{X}_{2}\right)\end{array}$ \\
\hline Basic level "0" & 2 & 1 \\
Lower level "-1" & 4 & 1.5 \\
Upper level "+1" & 6 & 2 \\
\hline Variation interval & 2 & 0.5 \\
\hline
\end{tabular}

utilizes the matrix approach to analyze regression and find the coefficients of the regression equations (Table 7).

The analysis of the regression coefficients is necessary to draw a number of technological conclusions.

Thus, the positive values of the coefficients $B_{1}$ and $B_{2}$ are indicative of the positive effect of drying and CMC on the strength of the granules. Conversely, the negative values of the coefficients $B_{11}$ and $B_{22}$ indicate the negative effect of the CMC content increase and drying time both on the strength and the bulk density of the granules. The isoparametric surfaces of change of the bulk density of the granules and boundary of compressive strength $\left(\mathrm{Y}_{1}, \mathrm{Y}_{2}=\right.$ const $)$ were constructed on the basis of the obtained regression equations (Fig. 2).
The results, obtained during the laboratory tests of the immersion type water transformation from different industry sectors, are shown in Table 8 . The materials with the bulk density of $445-615 \mathrm{~kg} / \mathrm{m}^{3}$ were obtained as a result of treatment of different mixtures.

An optimal match of the components in the raw mixture, wt.\%, was established based on the results of the conducted two-factor experiment: TPP fly ash - 60-65; $\mathrm{CaO}-5-8$; zeolite clinoptilolite - 15-20; silt from treatment of the communal wastewaters - 10-15, carboxylmethylcellulose $-5-10 \%$.

In order to determine the effect of the drying temperature of the granules, the studies, showing greater strength of the granules at the temperatures of $40-60{ }^{\circ} \mathrm{C}$, were conducted. The reduction of strength of the granules at higher temperatures is associated with the softening of heavy petroleum products and the evaporation of light petroleum products from the water treatment sludge (Fig. 3).

The obtained materials had the following average indicators of the granules according to the study results: bulk density $-450-550 \mathrm{~kg} / \mathrm{m}^{3}$; strength - 1.9-2.8 MPa; porosity - 30-39\%.

Thus, when using the oil-containing sludge after water treatment at the oil refineries, the optimal parameters for obtaining the highest strength granules $(2.69 \mathrm{MPa}$ ) at the lowest bulk density $\left(545 \mathrm{~kg} / \mathrm{m}^{3}\right)$ are considered to be the CMC consumption in the amount of 4 wt.\% under drying

Table 6. Planning matrix and results of the full two-factor experiment

\begin{tabular}{|c|c|c|c|c|c|}
\hline \multicolumn{2}{|c|}{ In normalized factors } & \multicolumn{2}{|c|}{ In natural factors } & Bulk density, $\mathrm{kg} / \mathrm{m}^{3}$ & Strength, MPa \\
\hline $\mathrm{X}_{1}$ & $\mathrm{X}_{2}$ & $\mathrm{CMC}, \mathrm{wt} . \%$ & Time, hour & $\mathrm{Y}_{1}$ & $\mathrm{Y}_{2}$ \\
\hline-1 & -1 & 2 & 1 & 410 & 1.23 \\
\hline-1 & 0 & 2 & 1.5 & 578 & 2.24 \\
\hline-1 & 1 & 2 & 2 & 530 & 2.31 \\
\hline 0 & -1 & 4 & 1 & 505 & 1.43 \\
\hline 0 & 0 & 4 & 1.5 & 589 & 2.52 \\
\hline 0 & 1 & 4 & 2 & 545 & 2.69 \\
\hline 1 & -1 & 6 & 1 & 615 & 2.56 \\
\hline 1 & 0 & 6 & 1.5 & 593 & 2.74 \\
\hline 1 & 1 & 6 & 2 & 550 & 2.95 \\
\hline
\end{tabular}

Table 7. Coefficients of the regression equations

\begin{tabular}{|c|c|c|c|c|c|c|}
\hline \multirow{2}{*}{ Response features } & \multicolumn{7}{c|}{ Regression coefficients } & $\mathrm{B}_{22}$ \\
\cline { 2 - 7 } & $\mathrm{B}_{0}$ & $\mathrm{~B}_{1}$ & $\mathrm{~B}_{2}$ & $\mathrm{~B}_{12}$ & $\mathrm{~B}_{11}$ & -0.833 \\
\hline \multicolumn{7}{|c|}{ Bulk density } \\
\hline $\mathrm{Y}_{1}$ & 591.889 & 10.833 & -44.167 & -2.500 & -7.833 & -0.472 \\
\hline $\mathrm{Y}_{2}$ & 2.528 & 0.245 & 0.622 & 0.078 & -0.042 & \\
\hline
\end{tabular}




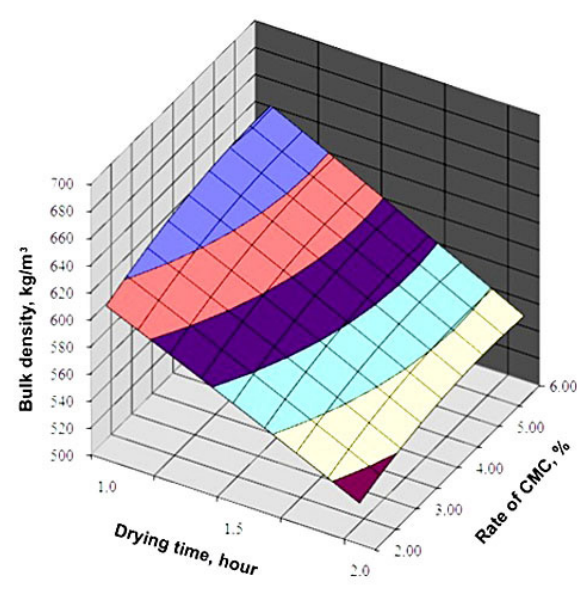

a

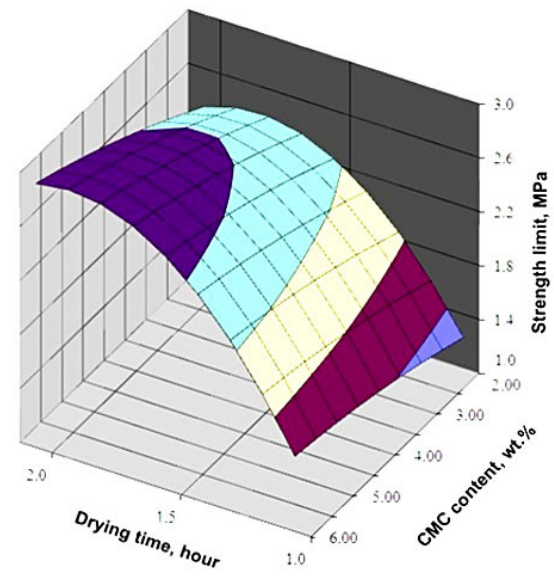

b

Fig. 2. Isoparametric surfaces change of the bulk density (a) and strength (b) of the granules

Table 8. Physical-and-mechanical properties of the granular materials

\begin{tabular}{|c|c|c|c|c|}
\hline Number of mix sample & Water absorption, $\%$ & Bulk density, $\mathrm{kg} / \mathrm{m}^{3}$ & Strength, MPa & Granule porosity, \% \\
\hline 1 & 5.9 & 445 & 1.34 & 83.3 \\
\hline 3 & 5.6 & 480 & 1.64 & 79.6 \\
\hline 5 & 5.4 & 405 & 2.05 & 75.5 \\
\hline 7 & 5.2 & 410 & 2.81 & 72.2 \\
\hline 8 & 5.0 & 490 & 2.78 & 70.5 \\
\hline 9 & 4.9 & 465 & 1.56 & 80.1 \\
\hline
\end{tabular}

conditions lasting for 2 hours with subsequent curing of these granules for 8-10 hours under the hood. The granules strength increased to 3.03.2 MPa under such conditions. The commercial size granules were formed with the diameter of 4-6 $\mathrm{mm}$ and length of $15-20 \mathrm{~mm}$. The moisture content in the developed composition after granulation was at the level of $30 \%$ and ground natural zeolite was added in order to prevent caking of the obtained granules at the drying stage.
These technologies make it possible to utilize a significant amount of the abovementioned silt at the temperature up to $60{ }^{\circ} \mathrm{C}$ that reduce their energy consumption during the thermal treatment of granules since combustion $\left(600-900{ }^{\circ} \mathrm{C}\right)$ does not occur - the environmental friendliness of the facilities, used to process such multi-tonnage wastes, is generally improved.

Therefore, depending on the composition of the prepared raw material, thermal treatment

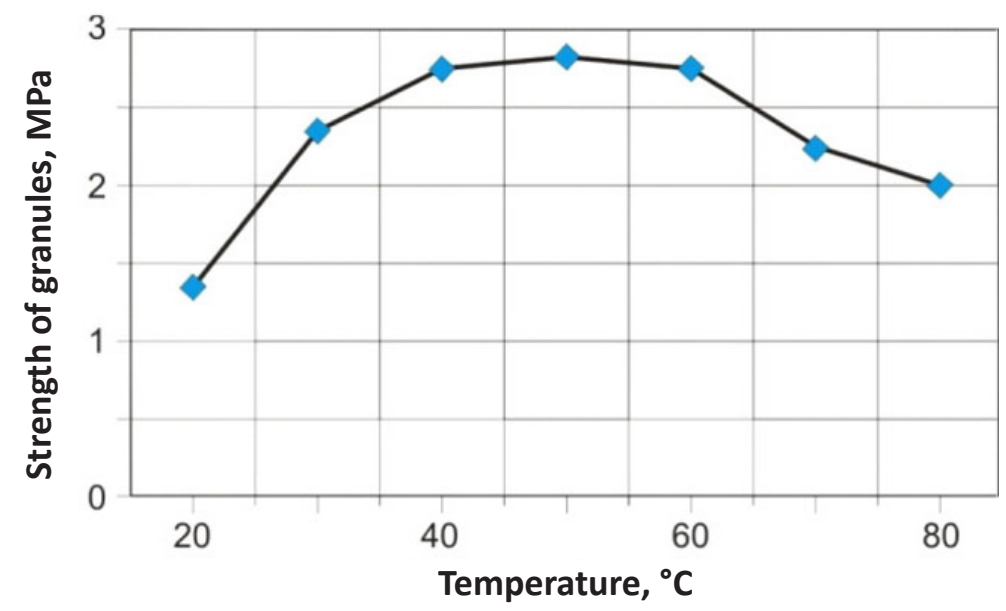

Fig. 3. Dependence of static strength on the granules drying temperature 
temperature, and products formation method, the materials with different properties and indicators (density, strength, and porosity), recommended after slight thermal treatment, are obtained.

\section{CONCLUSIONS}

1. The main technological parameter of the technology of treatment of oil sludge and municipal wastewaters is the composition of the raw mixture, which is based on the ratio of components and dry additives to obtain the products that meet the optimal indicators for use in the cement industry.

2. On the basis of the generalization of the results obtained from the theoretical and experimental studies on the treatment of fly ash from thermal power plants and other technogenic wastes, the technology, in which the raw material charge consists of the following components, wt.\%, was developed: fly ash - 25.0-38.2; water treatment sludge - 12.6-19.0; zeolite clinoptilolite - 27.0-31.5, carboxylmethylcellulose 3.1-4.8, and calcium-containing compounds - the remaining amount.

3. The developed technology is efficient due to the possibility to use technogenic production wastes and carry out the process at low temperatures at the expense of water absorption, providing for the formation of granular additives for cement production.

\section{REFERENCES}

1. Akhmetov A.F., Gaysina A.R., Mustafin I.A. 2011. Methods for utilization of different origin oil sludges. Oil and gas business, 9(3). 98-101.

2. Blinnikova O. (Ed.) 2018. Statistical yearbook of the Ivano-Frankivsk region for 2017. Main department of statistics in Ivano-Frankivsk oblast, IvanoFrankivsk. (in Ukrainian)

3. Bogoslavets M. 2018. Statistical report of the facility of JSC "Naftohimik Prykarpattya" in the form of "2-TP water system", "2-TP air", "2-TP solid waste, sludge" for 2015-2017, Nadvirna.

4. Borodin M. 2016. Challenges and prospects for development of Ukrainian oil and gas complex entities. Baltic Journal of Economic Studies, 2(3), 2328. DOI: $10.30525 / 2256-0742 / 2016-2-3-23-28$.

5. Brauweiler H.-C., Shkola V., Markova O. 2017. Economic and legal mechanisms of waste management in Ukraine. Journal "Marketing and Management of Innovations", 2, 359-368. DOI: 10.21272/ mmi.2017.2-33

6. Chelyadyn L.I., Sanytskyy M.A., Novosad P.V., Chelyadyn V.L. 2010. Patent for utility model UA 47233. B09B 3/00. Method of utilization of ash-slime waste.

7. Chelyadyn V.L., Novosad P.V., Chelyadyn L.I., Maruschak U.D. 2016a. Technology of complex recycling of anthropogenic waste. Vesnik of Brest University. Series 5. Chemistry. Biology. Sciences about Earth, 1, 5-12.

8. Chelyadyn V.L., Bogoslavets M.M., Chelyadyn L.I. 2016b. Processing technologies of technologenic waste into filter media for sewage treatment of industrial objects. In: H. Sobczuk, B. Kowalska (Eds.) "Water Supply and Wastewater Removal", Politechnika Lubelska, 15-25.

9. Chelyadyn L. 2018a. Ecotechnology of industrial projects in the region: monograph, Ivano-Frankivsk: NTUNG, $254 \mathrm{p}$.

10. Chelyadyn L.I., Novosad P.V., Skorokhoda V.J., Burylo O.P., Chelyadyn V.L. 2018b. Patent for utility model UA 122605. C04B 18/06, C04B 18/20, C04B 24/24, C04B 18/04, B01J 20/02, B01J 20/22. Raw material mixture of technogenic waste.

11. Dolina L.F. 2005. Modern technology and facilities for oil wastewater treatment. Dnepropetrovsk: Continent, 296 p. (in Russian).

12. Dvorkin L.J., Dvorkin O.L., Zhitkovsky V.V. 2011. Decision construction and technological problems by mathematical experiment planning. - Tutorial. Rivne: NUWM, 175 p. (in Ukrainian)

13. DSTU B V.2.7-170:2008 - Concretes. Methods for determining average density, humidity, water absorption, porosity and water resistance (in Ukrainian).

14. DSTU B V.2.7-214:2009 - Building materials. Concretes. Methods for determining the strength of control samples (in Ukrainian).

15. DSTU B V.2.7-264:2011 - Porous inorganic aggregates for construction work. Test methods (in Ukrainian).

16. Jamali S., Gima A., Hasan S.W. 2015. Recent improvements in oily wastewater treatment: Progress, challenges, and future opportunities, Journal of Environmental Sciences, 37, 15-30. DOI: 10.1016/j. jes.2015.04.011.

17. Johnson O.A. and Affam A.C. 2019. Petroleum sludge treatment and disposal: A review. Environmental Engineering Research, 24(2), 191-201. DOI: 10.4491/eer.2018.134.

18. Mazlova E.A. and Meshcheryakov S.V. 2001. The problem of disposal of sludge and methods for their processing. Moscow: Publishing House "Noosphere", 56 p. (in Russian). 
19. Nadesan M.S., Dinakar P. 2017. Structural concrete using sintered flyash lightweight aggregate: A review. Construction and Building Materials, 154, 928-944. DOI: 10.1016/j.conbuildmat.2017.08.005.

20. Nazarov V.D., Nazarov M.V., Razumov V.Ju. 2013. RU 2490305. C10G 1/00, C10G 33/00, C02F 1/465. Method for treatment of stable oil emulsified crude and used oil sludge.

21. Novosad P.V., Chelyadyn L.I., Chelyadyn V.L. 2009. Thermal insulation materials based on technogenic wastes. Bulletin of Lviv Polytechnic National University, series "Theory and Building Practice", 655, 208-213.

22. Novosad P.V., Poznyak O.R., Melnyk V.M., Braichenko S.P. 2020. Porous thermal insulation materials on organic and mineral fillers. In: Z. Blikharskyy, P. Koszelnik, P. Mesaros (Eds.), Proceedings of CEE 2019 “Advances in Resource-saving Technologies and Materials in Civil and Environmental Engineering" - Book Series V. 47: Lecture Notes in Civil Engineering, Springer International Publishing, 354-360.

23. Prokopenko O. (Ed.). 2018. Statistical yearbook. Environment of Ukraine 2017. State Statistics Service of Ukraine, Kyiv (in Ukrainian).

24. Rudiuk M.V., Markina L.M., Koval O.M. 2006. Patent for the invention UA 74635. C10G 1/00,
F23G 5/027. Method for thermal utilization of oil slime and installation for its realization.

25. Stechyshyn M., Sanytskyy M., Poznyak O. 2015. Durability properties of high volume fly ash selfcompacting fiber reinforced concretes. Eastern-European Journal of Enterprise Technologies, 3/11(75), 49-54. DOI: 10.15587/1729-4061.2015.44246.

26. Tsymbalyuk A. 2011. Genadi Man: "Ukrainian scientists have learned to return to" waste "production hydrocarbons". Gazeta-2000 https:// www.2000.ua, 17 (556) 29 april - 5 may. (in Russian). 17556_456347.pdf

27. Vambol S.O., Strokov O.P., Vambol V.V., Kondratenko O.M. 2015. Modern methods for improving the ecological safety of power plants exploitation: monograph. Kharkiv: NAKU, 212 p. (in Ukrainian).

28. Vdovenko S., Boichenko S., Kochubei V. 2015. Composition and properties of the refinery oily sludge. Chemistry and Chemical Technology, 9(2), 257-260, (in Ukrainian) DOI: 10.23939/ chcht09.02.257.

29. Vozniuk V.I., Shapovalova L.P. Patent for the invention UA 76956. B09B 3/00, B09C 1/00, B08B 3/04, B01D 11/04. Method for processing oil slimes (2006). 